\title{
Structural complexity and species composition of Potrero Grande and Santa Elena mangrove forests in Santa Rosa National Park, North Pacific of Costa Rica
}

\author{
Margarita Loría-Naranjo ${ }^{1}$, Jimena Samper-Villarreal ${ }^{1} \&$ Jorge Cortés ${ }^{1,2}$ \\ 1. Centro de Investigación en Ciencias del Mar y Limnología (CIMAR), Ciudad de la Investigación, Universidad de \\ Costa Rica, San Pedro, 11501-2060 San José, Costa Rica; maggie.loria@gmail.com, jimena.samper@gmail.com, \\ jorge.cortes@ucr.ac.cr \\ 2. Escuela de Biología, Universidad de Costa Rica, San Pedro, 11501-2060 San José, Costa Rica.
}

\author{
Received 13-II-2014. Corrected 04-VIII-2014. Accepted 27-IX-2014.
}

\begin{abstract}
The mangroves of the North Pacific of Costa Rica are among the most altered coastal ecosystems in the country. Scientific information about their physiology, ecology, structure, and geochemistry is limited. This study analyzed the structural complexity and species composition of Potrero Grande and Santa Elena mangrove forests. Two visits were carried out to each mangrove between May and June 2012. The Point-Centered Quarter Method was used to determine forest structure. Mangrove species, height, diameter at breast height, and canopy density were noted at multiple points along transects. Associated fauna and cover of epiphytic macroalgae were recorded when present. Interstitial water salinity was determined at each point. Basal area, dominance, importance value, and density were calculated for each mangrove species and complexity index for the forests. Rhizophora racemosa had the highest relative dominance and importance value at both sites. Santa Elena had the highest complexity index ( $\mathrm{CI}=26.9)$, this could be due to the high density found. Potrero Grande mangrove is one of the best developed mangrove forests on the Pacific coast of Costa Rica, given its structural characteristics (relatively tall trees and high tree trunk diameters) and species composition. While Pelliciera rhizophorae was known to have reached its northern limit at the Potrero Grande mangrove; this study extends its distribution further north for the Pacific coast of Costa Rica. Unlike Potrero Grande, Santa Elena is not adjacent to a marine protected area, resulting in uncontrolled extraction and tourism activities within Santa Elena Bay. The creation of a marine protected area in Santa Elena Bay is recommended to provide enhanced protection to this ecosystem. Rev. Biol. Trop. 62 (Suppl. 4): 33-41. Epub 2014 Diciembre 01.
\end{abstract}

Key words: Potrero Grande, Santa Elena Bay, forest structure, The Point-Centered Quarter Method.

Mangrove ecosystems have a latitudinal distribution between $30^{\circ} \mathrm{N}$ and $30^{\circ} \mathrm{S}$, and it is estimated that they cover an area of about 300 $000 \mathrm{~km}^{2}$ worldwide (Kathiresan \& Bingham, 2001; Nellemann Corcoran, Duarte, Valdés, De Young, Fonseca, Grimsditch, 2009). In Costa Rica there are mangrove forests on both coasts, however $99 \%$ of these are found on the Pacific coast (Zamora-Trejos \& Cortés, 2009). Mangroves on the Pacific coast of Costa Rica are divided into three main regions: North, Central, and South (Jiménez, 1994). North Pacific mangroves extend from the outer section of the Gulf of Nicoya to the Nicaraguan border. The forest structure and species composition of North Pacific mangroves of Costa Rica has been studied in Santa Rosa (Pool, Snedaker \& Lugo, 1977), Tamarindo (Jiménez, 1981), Puerto Soley (Soto \& Jiménez, 1982), and Panamá and Iguanita (Samper-Villarreal, Cortés \& Benavides-Varela, 2012). Other than these, there are only brief qualitative descriptions in Córdoba-Muñoz, Romero-Araya, and Windevoxhel-Lora (1998), Ramsar data sheet (1999) and in Zamora-Trejos and Cortés (2009). Mangroves in the North Pacific are the 
least structurally developed mangroves on the Pacific coast of Costa Rica due to an extended annual dry season (Silva-Benavides, 2009).

North Pacific mangroves are among the most altered coastal ecosystems of Costa Rica (Silva-Benavides, 2009) yet scientific information about their physiology, ecology, structure, and geochemistry is very limited (SamperVillarreal et al., 2012; Zamora-Trejos \& Cortés, 2009). Mangrove ecosystems in Costa Rica are legally protected by national and international laws (Jiménez, 1994; Pizarro \& Angulo, 1994; Zamora-Trejos \& Cortés, 2009). However, multiple anthropogenic impacts such as deforestation, agriculture, aquaculture, change in land use, and tourism are common threats to these ecosystems.

Potrero Grande and Santa Elena mangrove forests are both within the terrestrial domains of Santa Rosa National Park, in the Guanacaste Conservation Area. Potrero Grande mangrove was declared a Ramsar site in 1999, partly because of the presence of an important population of Pelliciera rhizophorae, a rare mangrove species in the North Pacific of Costa Rica. Before its protection, agriculture and logging were practiced within the Potrero Grande mangrove forest and in adjacent areas, negatively affecting its conservation and development (Ramsar, 1999). Santa Elena mangrove forest is in the Santa Elena Bay and, unlike Potrero Grande, it does not include an adjacent marine protected area.

The aim of this study was to determine, for the first time, the species composition and describe the structural complexity of the mangrove forests of Potrero Grande and Santa Elena, North Pacific coast of Costa Rica.

\section{METHODOLOGY}

Study sites: Potrero Grande mangrove forest $\left(10^{\circ} 85^{\prime} 65^{\prime \prime} \mathrm{N}-85^{\circ} 79^{\prime} 39^{\prime \prime} \mathrm{W}\right)$ is located between the Boquerones and Potrero Grande rivers, with a total estimated area of $1.39 \mathrm{~km}^{2}$ (Córdoba-Muñoz et al., 1998). The Santa Elena mangrove forest (Punta Piedra sector, associated with Grande Estuary) is on the eastern side

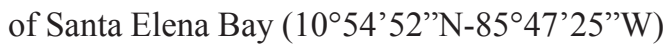
(Fig. 1). Santa Elena is associated with two streams: Grande and Cachimbo, and has a small extension, with an estimated area of $0.16 \mathrm{~km}^{2}$ (Biomarc Project, pers. comm., 2013). Santa Elena Bay is in the Santa Elena Peninsula, with sandy beaches in its inner section and coral reefs present in its outer reaches (Cortés \& Jiménez, 2003).

The study area has an annual precipitation of $1735 \mathrm{~mm}$ and a mean temperature of $26.5^{\circ} \mathrm{C}$ (IMN, 2012). In Potrero Grande, total rainfall for May 2012 was $291 \mathrm{~mm}$, and the average temperature $29.3^{\circ} \mathrm{C}$ (IMN, 2012). In Santa Elena, during June 2012, total rainfall was $144.7 \mathrm{~mm}$ and mean temperature was $26.5^{\circ} \mathrm{C}$ (IMN, 2012).

Forest structure: Visits to the study sites took place on May and June 2012. The PointCentered Quarter Method - PCQM (Cintrón \& Schaeffer-Novelli, 1984) was used to determine mangrove forest structure. At each mangrove forest, two linear transects were carried out perpendicular to the coastline, up to $200 \mathrm{~m}$ maximum length. Adjacent points were separated by $20 \mathrm{~m}$ to avoid overlap of trees. A total of 20 points were analyzed in Potrero Grande and 14 points in Santa Elena. Coordinates were obtained at each point with a GPS. Canopy density was estimated using a densiometer at four cardinal points. The area surrounding the point was divided into four quadrants. In each quadrant the nearest mangrove tree to the center of the point with diameter $\geq 2.5 \mathrm{~cm}$ was selected. Distance from the center point to the tree was noted, as well as species, height, and circumference at breast height $(\mathrm{CBH})$, then converted to diameter at breast height (DBH). Heights of the trees were calculated by visual estimations given that the use of a clinometer was not possible where canopy density was too high.

When possible, at each point a hole was dug in the soil to take a sample of interstitial water. Water salinity was determined using a hand-held refractometer. When epiphytic macroalgae were present on mangrove roots, 


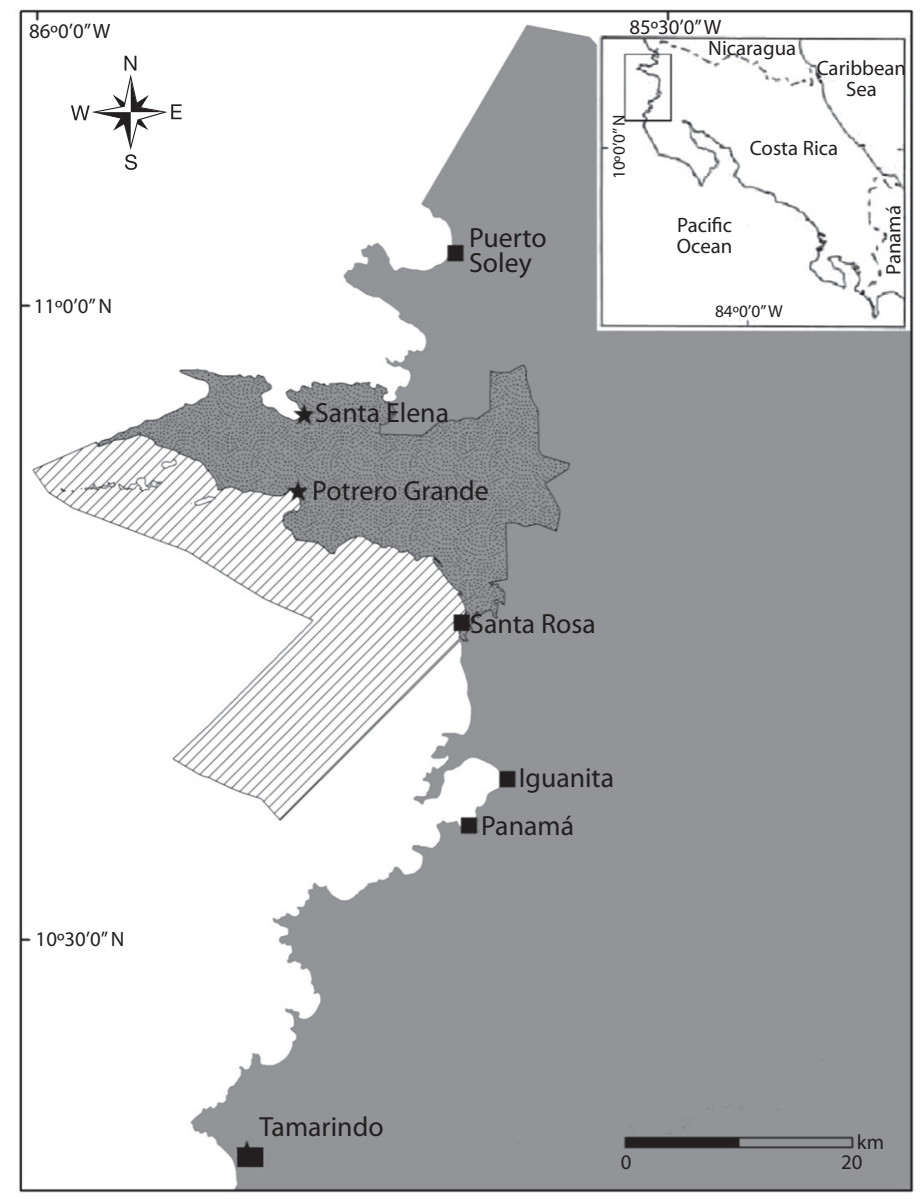

Fig. 1. North Pacific mangrove study sites Potrero Grande and Santa Elena (stars) within Santa Rosa National Par (dark grey with pattern) and adjacent marine protected area (white with stripes). Previous studies (squares) Santa Rosa (Pool et al., 1977); Puerto Soley (Soto \& Jiménez, 1982); Iguanita and Playa Panamá (Samper-Villarreal et al., 2012).

percentage cover was estimated and the algae were collected for identification to the lowest possible taxon. Associated fauna was noted when present. General observations of the soil composition were made in the field.

Species density, basal area, dominance, importance value, and the complexity index for the stands were calculated based on Cintrón and Schaeffer-Novelli (1984). Although Cintrón and Schaeffer-Novelli (1984) recommend a minimum of 20 points when using PCQM to determine forest structure, for Santa Elena only 14 points were sampled. This sample is considered to be representative because of limited overall mangrove extension. This is a very small mangrove $\left(0.16 \mathrm{~km}^{2}\right)$ if we compare it with other mangrove forests of the region, such as Puerto Soley $\left(2 \mathrm{~km}^{2}\right)$ and Tamarindo $\left(4 \mathrm{~km}^{2}\right)$ (Jiménez, 1999).

To achieve normality, data were transformed to the Fourth root. Statistical comparison of forest structure between Potrero Grande and Santa Elena was tested using One Way Multivariate Analysis of Variance (MANOVA), these tests were carried out in PAST (3.x version). Mean canopy cover for the mangrove forest was calculated. Also differences in canopy coverage depending on the species were analyzed with Analysis of Variance (ANOVA). To consider canopy coverage by species, only 
those points in which the four individuals were from the same species were selected for this analysis, these analyses were carried out in JMP ( $7^{\text {th }}$ version $)$.

\section{RESULTS}

Potrero Grande mangrove forest: Five mangrove species were encountered: Avicennia germinans, Laguncularia racemosa, Rhizophora mangle, Rhizophora racemosa and P. rhizophorae (Table 1). Four Pithecellobium sp. trees were present inside the quadrants but were not taken into account for forest structure analysis because it is not considered a mangrove species per se (the structure analysis includes 76 individuals). There were also a few individuals of Avicennia bicolor, but these were observed outside the transects. Avicennia germinans, A. bicolor, and L. racemosa were flowering in May 2012.

Mean tree height and DBH for this forest were higher than for the Santa Elena mangrove (Table 1). Rhizophora racemosa had the highest relative dominance among the five species (Table 2). Total density of the stand was 112.0 stems/0.1ha. Canopy coverage was approximately $17.2 \pm 10.9 \%$. The complexity index for this forest was 19.0, but when A. bicolor individuals observed outside the transects are included, the complexity index increased to 22.8 .

No macroalgae were found in association with the roots of mangrove trees. During several occasions crabs of the Grapsidae family were seen on dead trunks of several mangrove species. There was also an individual of Crocodylus acutus.

In Potrero Grande, superficial soil composition varied between fractions of peat, stone, mud and sand, and in some places presented a large litter fraction. Only in a few points was it possible to obtain samples for interstitial salinity determination, which averaged $30.8 \pm 4.8$ PSU.

Santa Elena mangrove forest: Six mangrove species were found: $A$. germinans, $A$. bicolor, L. racemosa, $R$. mangle, $R$. racemosa, and $P$. rhizophorae. Individuals of $P$. rhizophorae were noted in the inner edge of the mangrove forest near freshwater sources;

TABLE 1

Mean mangrove tree height, diameter at breast height (DBH), and number of trees per species at Potrero Grande and Santa Elena mangrove forests, Parque Nacional Santa Rosa, North Pacific of Costa Rica

\begin{tabular}{lccccc}
\multicolumn{1}{c}{ Location } & $\begin{array}{c}\text { Mean height } \\
\pm \mathrm{SE}(\mathrm{m})\end{array}$ & $\begin{array}{c}\text { Min-Max } \\
\text { height }(\mathrm{m})\end{array}$ & $\begin{array}{c}\text { Mean DBH } \\
\pm \mathrm{SE}(\mathrm{cm})\end{array}$ & $\begin{array}{c}\text { Min-Max } \\
\mathrm{DBH}(\mathrm{cm})\end{array}$ & Number of trees \\
Potrero Grande & $8.8 \pm 0.6$ & $2.0-20.0$ & $16.1 \pm 1.5$ & $0.5-77.4$ & 76 \\
All species & $9.3 \pm 1.2$ & $1.5-15.0$ & $26.8 \pm 7.4$ & $0.5-77.4$ & 9 \\
Avicennia germinans & $6.0 \pm 0.6$ & $2.5-9.0$ & $11.9 \pm 1.8$ & $2.7-21.5$ & 15 \\
Laguncularia racemosa & $7.8 \pm 1.5$ & $2.0-16.0$ & $12.8 \pm 2.7$ & $3.2-27.7$ & 12 \\
Pelliciera rhizophorae & $5.0 \pm 0.6$ & $3.0-8.0$ & $7.0 \pm 0.9$ & $2.8-11.8$ & 9 \\
Rhizophora mangle & $12.0 \pm 0.8$ & $3.0-20.0$ & $19.3 \pm 2.6$ & $3.3-73.2$ & 31 \\
Rhizophora racemosa & & & & & \\
Santa Elena & $7.0 \pm 0.4$ & $2.0-13.0$ & $13.9 \pm 1.2$ & $2.5-39.2$ & 56 \\
All species & 4.0 & - & 6.7 & - & 1 \\
Avicennia bicolor & $9.0 \pm 1.5$ & $6.0-11.0$ & $26.3 \pm 2.2$ & $22.3-29.6$ & 3 \\
Avicennia germinans & $7.5 \pm 0.9$ & $4.0-12.0$ & $19.1 \pm 3.3$ & $11.5-36.0$ & 8 \\
Laguncularia racemosa & 7.0 & - & 10.2 & - & 1 \\
Pelliciera rhizophorae & $5.3 \pm 0.6$ & $2.0-12.0$ & $9.1 \pm 1.6$ & $2.6-3.8$ & 20 \\
Rhizophora mangle & $8.2 \pm 0.6$ & $2.5-13.0$ & $15.0 \pm 1.8$ & $3.0-39.2$ & 23 \\
Rhizophora racemosa & & &
\end{tabular}


TABLE 2

Number of points with species, absolute density, basal area, relative density and frequency, and importance value per species at Potrero Grande and Santa Elena mangrove forests, Parque Nacional Santa Rosa, North Pacific of Costa Rica

\begin{tabular}{|c|c|c|c|c|c|c|c|}
\hline Location & $\begin{array}{l}\text { Points with } \\
\text { species }\end{array}$ & $\begin{array}{l}\text { Absolute density } \\
\text { (stems } / 0.1 \text { ha) }\end{array}$ & $\begin{array}{l}\text { Basal area } \\
\left(\mathrm{m}^{2} / 0.1 \mathrm{ha}\right)\end{array}$ & $\begin{array}{c}\text { Relative } \\
\text { density (\%) }\end{array}$ & $\begin{array}{c}\text { Relative } \\
\text { dominance }(\%)\end{array}$ & $\begin{array}{c}\text { Relative } \\
\text { frequency }(\%)\end{array}$ & $\begin{array}{c}\text { Importance } \\
\text { value }(\%)\end{array}$ \\
\hline \multicolumn{8}{|l|}{ Potrero Grande } \\
\hline Avicennia germinans & 5 & 12.6 & 1.1 & 11.8 & 26.7 & 16.2 & 18.2 \\
\hline Laguncularia racemosa & 7 & 21.0 & 0.3 & 19.7 & 7.2 & 22.6 & 16.5 \\
\hline Pelliciera rhizophorae & 4 & 16.8 & 0.3 & 15.8 & 7.5 & 13.0 & 12.0 \\
\hline Rhizophora mangle & 4 & 12.6 & 0.1 & 11.8 & 13.2 & 12.9 & 12.6 \\
\hline Rhizophora racemosa & 11 & 43.4 & 1.9 & 40.8 & 45.3 & 35.5 & 40.5 \\
\hline TOTAL & 20 & - & 3.8 & 100 & 100 & 100 & 100 \\
\hline \multicolumn{8}{|l|}{ Santa Elena } \\
\hline Avicennia bicolor & 1 & 3.1 & 0.0 & 1.8 & 0.3 & 4.3 & 2.1 \\
\hline Avicennia germinans & 2 & 9.2 & 0.5 & 5.4 & 13.7 & 8.7 & 9.2 \\
\hline Laguncularia racemosa & 4 & 24.6 & 0.8 & 14.3 & 23.1 & 17.4 & 18.2 \\
\hline Pelliciera rhizophorae & 1 & 3.1 & 0.0 & 1.8 & 0.7 & 4.3 & 2.3 \\
\hline Rhizophora mangle & 7 & 61.6 & 0.6 & 35.7 & 17.3 & 30.4 & 27.8 \\
\hline Rhizophora racemosa & 8 & 70.8 & 1.7 & 41.1 & 45.0 & 34.8 & 40.2 \\
\hline TOTAL & 14 & - & 3.7 & 100 & 100 & 100 & 100 \\
\hline
\end{tabular}

these trees were flowering in June 2012. Mean tree height and DBH for all mangrove species is presented in Table 1. The complexity index for this forest was 26.9. As in Potrero Grande, $R$. racemosa was the species with the highest relative dominance, while $P$. rhizophorae presented the lowest value (Table 2). Total density of the stand was 172.4 stems/0.1ha. Canopy coverage was $62.5 \pm 17.1 \%$.

Macroalgae cover on the roots was estimated as $6 \%$, of which two species were identified: Ulva prolifera and Cladophora sp. Crabs (Grapsidae), barnacles, and the gastropods Nerita scabricosta and Cerithia sp. were observed on the mangrove roots.

Different soil types were noted: such as peat soil, mud, and stones, leaf litter, and oyster shells. The ground covered by oysters was observed especially in parts of the outer edge of the mangroves, in direct contact with the sea, and leaf litter in the innermost parts. Interstitial salinity averaged $31.9 \pm 1.5$ PSU.

In both forests, $R$. racemosa was the dominant species, but in Santa Elena compared to Potrero Grande, this species presented the lowest average DBH within the stand $(15.0 \pm 1.8 \mathrm{~cm})$. Potrero Grande presented higher average canopy height $(8.8 \pm 0.6 \mathrm{~m})$ and wider mean DBH $(16.1 \pm 1.5 \mathrm{~cm})$ compared to Santa Elena $(7.0 \pm 0.4 \mathrm{~m}$ and $13.9 \pm 1.2 \mathrm{~cm}$, respectively).

Mean DBH and height between Potrero Grande $(16.1 \pm 1.5 \mathrm{~cm}$ and $8.8 \pm 0.6 \mathrm{~m})$ and Santa Elena $(13.9 \pm 1.2 \mathrm{~cm}$ and $7.0 \pm 0.4 \mathrm{~m})$ were not significantly different (MANOVA, $\mathrm{F}=2.5$; $\mathrm{p}=0.081$ ). On the other hand, DBH and heights show significant differences among mangrove species (MANOVA, $\mathrm{F}=6.9 ; \mathrm{p} \leq 0.001$ ). In both mangrove forests, A. germinans presented the highest mean DBH. In Potrero Grande, $R$. racemosa was the tallest species, whereas in Santa Elena it was $A$. germinans. There was a significant difference between canopy coverage of $R$. racemosa, $R$. mangle, L. racemosa and P. rhizophorae (ANOVA, $\mathrm{F}=6.2 ; \mathrm{p} \leq 0.005$ ), generally observing a higher canopy density in the points dominated by $R$. mangle.

\section{DISCUSSION}

This study describes the structural complexity and species composition of Potrero Grande and Santa Elena mangrove forests in the North Pacific of Costa Rica. While this 
is a preliminary description, it is the first time an analysis of this kind is performed in these mangrove forests, which is needed to understand more about their ecology and for conservation purposes.

In the UICN Red List of Threatened Species, Ellison, Farnsworth and Moore (2010) reported $P$. rhizophorae as a vulnerable species with a restricted distribution from northern Ecuador to southern Nicaragua, where it occurs in patches (Castillo-Cárdenas, Toro-Perea \& Cárdenas-Henao, 2005). However, Jiménez (1984) reported that the distribution of $P$. rhizophorae reached its northern limit at Potrero Grande. In this study several individuals of $P$. rhizophorae were found in Santa Elena, which extends its known distribution further north for the Pacific coast of Costa Rica.

It has been reported that North Pacific mangrove trees should not be taller than $15 \mathrm{~m}$ (Jiménez, 1999). However, at Potrero Grande, trees of about $20 \mathrm{~m}$ high were found. These trees are considerably taller than expected, especially when compared with average tree heights in South Pacific mangroves, such as in Sierpe (10.8m) and Quepos (15.6m) (Jiménez $\&$ Soto, 1985). This could possibly be due to the higher amount of available fresh water in Potrero Grande compared to other mangrove forests in the North Pacific of Costa Rica. Nevertheless, it should be taken into account that the heights of the threes in Potrero Grande and Santa Elena were measured by visual estimation, and represent an approximate measurement. Height comparisons between sites must be carefully interpreted.

Species composition remained the same moving inland, therefore no zonation pattern was found in Potrero Grande or Santa Elena mangrove forests. The species with the highest relative dominance was $R$. racemosa, both in Potrero Grande and Santa Elena. Avicennia germinans is supposed to dominate North Pacific mangrove forests because of the dryness of the region (Jiménez \& Soto, 1985; Jiménez, 1999). Such as at Playa Panamá where it is the dominant species (Samper-Villarreal et al., 2012) and at Tamarindo where it is A. bicolor
(Jiménez, 1981) (Fig. 1). Nevertheless, in both mangrove forest studied here, $R$. racemosa was the species with the highest importance value, absolute density and basal area. Puerto Soley mangrove forest was dominated by $R$. harrisonii (Soto \& Jiménez, 1982), which could have been $R$. racemosa due to the high degree of hibridization between both species (Jiménez, 1994). Iguanita mangrove forest was dominated by $R$. mangle, though further study during the reproductive period was suggested to fully exclude the possibility of this species being $R$. racemosa (Samper-Villarreal et al., 2012). Dominance by Rhizophora might be linked to specific hydrodynamic conditions at these mangroves that differ from those expected for mangroves in the North Pacific.

In the seaward stands of dry regions, Rhizophora is expected to be the species that presents higher basal areas, while Avicennia presents the higher basal areas in the inner stands, where water is scarce and seepage rare (Jiménez, 1999). Jiménez and Soto (1985) found a high positive correlation between forest structure and extension, and climatic and hydrologic conditions. South Pacific mangroves are extensive and have well developed forests, attributed to higher precipitation and larger river basins. This pattern, found by Jiménez and Soto (1985), could explain the wider and taller trees in Potrero Grande compared to Santa Elena, as Potrero Grande is irrigated by two rivers (Boquerones and Potrero Grande), forming a deltaic profile, and thereby more water is available throughout the forest. Whereas there are only two small streams present in Santa Elena (Grande and Cachimbo).

Iguanita, as well as Santa Elena, is dominated by Rhizophora. Higher vegetative development at Iguanita has been linked to its intensive influx of freshwater and associated nutrient input (Samper-Villarreal et al., 2012). Furthermore, Iguanita is located in the inner part of Culebra Bay, most likely linked to higher inundations (Samper-Villarreal et al., 2012). Santa Elena mangrove is also located in the inner part of a bay, however, this forest cannot be considered a riverine forest as it has 
a very short extension and is irrigated by two small streams (Grande and Cachimbo). Interstitial salinity found in Santa Elena was higher than in Potrero Grande, since smaller trees are expected to be found with higher salinities (Soto \& Jiménez, 1982), this fact could also help explain differences with tree sizes between sites.

The complexity index (IC) has been used in the study of mangrove forest structure previously, and it integrates different forest structure measures such as basal area, stand density, height and number of species (Pool et al., 1977). In the North Pacific, Santa Elena had a higher complexity index $(\mathrm{CI}=26.9)$ than the mangrove forests of Potrero Grande $(\mathrm{CI}=25.9)$, Puerto Soley (Soto \& Jiménez, 1982; CI=17.3), Santa Rosa (Pool et al., 1977; CI=4.9), and Playa Panamá (Samper-Villarreal et al., 2012; $\mathrm{CI}=1.1$ ). This could be due to a relatively high stand density at Santa Elena. However, Iguanita mangrove forest has the highest complexity index recorded for the region (Samper-Villarreal et al., 2012; $\mathrm{CI}=86.5)$. It is important to note that the studies compared here were carried out using different sampling methods, so there are likely inherent variations due to the different methods used among studies.

On the other hand, South Pacific mangroves normally present high $\mathrm{CI}$, such as in Quepos $(\mathrm{CI}=65.3)$ and Sierpe $(\mathrm{CI}=54.3)$, associated to higher densities (185 and 160 stems/0.1ha, respectively). Higher rainfall in the South Pacific results in taller and wider trees (Jiménez \& Soto, 1985), when compared with North Pacific mangroves. Further studies on climatic and hydrologic conditions in North Pacific mangroves are needed in order to understand their potential structural and ecological dynamics.

Avicennia germinans and $P$. rhizophorae were flowering in May (Santa Elena) and June (Potrero Grande) respectively. Flowering of A. germinans coincides with the observations by Jiménez (1988) that this species flowers in the dry season, between January and May.
However, $P$. rhizophorae is expected to have a distinct flowering season from December to March (Jiménez, 1999). Also A. bicolor was observed flowering in May 2012, in contrast to Jiménez (1988), who established flowering of this species at the onset of the dry season, especially in January.

The mangrove species found during this study at Potrero Grande coincide with the species that were listed in the Ramsar site sheet (Ramsar, 1999). Given its structural characteristics and diversity, Potrero Grande mangrove can be considered as one of the most developed mangroves of the North Pacific of Costa Rica. However, Santa Rosa mangrove had a higher mean height $(10 \mathrm{~m})$ (Pool et al., 1977), and Iguanita mangrove had the highest complexity index for the region (Samper-Villarreal et al., 2012).

Because of the relative good condition of the Potrero Grande and Santa Elena mangrove forests, it is important that their protection continues and illegal destructive activities stopped. The recovery of Potrero Grande mangrove surface area and development of its forest structure are evident after its protection started (Ramsar, 1999). The adjacent land stopped being used for agriculture or logging more than forty years ago (Ramsar, 1999). Potrero Grande mangrove is part of Santa Rosa National Park and adjoining a marine protected sector as is also the Playa Naranjo mangrove (Zamora-Trejos \& Cortés, 2009). However, illegal fishing is still an occasional activity (Ramsar, 1999) due to the difficult land access to the site and lack of a ranger station on the beach to monitor the area. Santa Elena mangrove belongs to the Murciélago Sector of Santa Rosa National Park. However, Santa Elena is not adjacent to any marine protected area. This allows unregulated extraction and tourism activities in Santa Elena Bay. These activities could seriously affect the stability of this mangrove forest in the future. The creation of a marine protected area in Santa Elena Bay is recommended to conserve this ecosystem. 


\section{ACKNOWLEDGMENTS}

The authors thank Allan Carrillo, Aldo Farah, and Cipriano Ardón for assistance in the field, and Cindy Fernández with algae identification. Roger Blanco and the Santa Rosa National Park's rangers greatly helped during our visits to the sites. Thanks to Katherine Bernal who elaborated the map and Jeffrey SibajaCordero with statistical support. Funding was provided by the German Agency for Cooperation (GiZ) through their BIOMARC Project, and the Asociación Costa Rica por Siempre. Additional funding and logistic support was provided by the Centro de Investigación en Ciencias del Mar y Limnología (CIMAR), Vicerrectoría de Investigación, Universidad de Costa Rica (Project 808-B2-400).

\section{RESUMEN}

La mayoría de los manglares del Pacífico Norte de Costa Rica son de los más impactados en el país. Además, la información científica sobre la fisiología, ecología, estructura y geoquímica de estos manglares es limitada. Este estudio analizó la complejidad estructural y composición de especies de dos bosques de manglar del Pacífico Norte: Potrero Grande y Santa Elena. Las visitas al campo se realizaron entre mayo y junio del 2012. Se utilizó el método deCuadrantes Centrados en un Punto (PCQM) para estudiar la estructura del bosque. Se anotó las especies de mangle, altura, diámetro a la altura del pecho (DAP) y densidad del dosel en diez puntos a lo largo de cada transecto. Así mismo, se registró la fauna asociada y cobertura de macroalgas epífitas sobre las raíces de mangle. En cada punto se determinó la salinidad de agua intersticial. Se calculó la densidad, área basal, dominancia, valor de importancia e índice de complejidad. Rhizophora racemosa fue la especie con mayor dominancia relativa y valor de importancia para ambos sitios. Santa Elena es el manglar con el mayor índice de complejidad ( $\mathrm{IC}=26.9$ ), lo cual podría deberse a la alta densidad encontrada. Potrero Grande es considerado como uno de los manglares más desarrollados de la costa del Pacífico Norte de Costa Rica, dadas sus características estructurales (árboles con grandes alturas y DAP)y de composición de especies. La distribución conocida de Pelliciera rhizophorae en Costa Rica alcanzaba su límite norte en el manglar de Potrero Grande; sin embargo, este estudio extiende esta distribución más al norte, ya que se encontraron algunos individuos en Santa Elena. A diferencia de Potrero Grande, Santa Elena no cuenta con un sector marino protegido adyacente, esto ha resultado en la extracción de recursos y actividades turísticas incontroladas en la zona. Se recomienda la creación de un área de protección marina en la Bahía de Santa Elena para que sirva de zona de amortiguamiento al manglar.

Palabras clave: Potrero Grande, Bahía Santa Elena, estructura del bosque, Método de los Cuadrantes Centrados en un Punto.

\section{REFERENCES}

Castillo-Cárdenas, M., Toro-Perea, N., \& Cárdenas-Henao, H. (2005). Population Genetic Structure of Neotropical Mangrove Species on the Colombian Pacific Coast: Pelliciera rhizophorae (Pellicieraceae). Biotropica, 37, 266-273.

Cintrón, G., \& Schaeffer-Novelli, Y. (1984). Methods for studying mangrove structure. In: S. C. Snedaker, \& J. G. Snedaker (Eds.), The Mangrove Ecosystem: Research Methods (pp. 91-113). UNESCO. Bungay, United Kingdom: The Chauser Press.

Córdoba-Muñoz, R., Romero-Araya, J. C., \& Windevoxhel-Lora, N. J. (1998). Inventario de los humedales de Costa Rica. San José, Costa Rica: UICN, MINAE, SINAC, Embajada Real de los Países Bajos.

Cortés, J., \& Jiménez, C. (2003). Corals and coral reefs of the Pacific of Costa Rica: history, research and status. In: J. Cortés (Ed.), Latin American Coral Reefs (pp.361-385).Amsterdam: Elsevier Science B.V.

Ellison, A., Farnsworth, E. \& Moore, G. (2010). Pelliciera rhizophorae. The IUCN Red List of Threatened Species. Retrieved from www.iucnredlist.org.

IMN (2012). Datos de la Estación Meteorológica Santa Elena $\left(10^{\circ} 55^{\prime} \mathrm{N} 85^{\circ} 36^{\prime} \mathrm{W}\right)$ e Isla San José $\left(10^{\circ} 51\right.$ 'N $\left.85^{\circ} 54^{\prime} W\right)$. San José, Costa Rica: Instituto Meteorológico Nacional.

Jiménez, J.A. (1981). The Mangrove of Costa Rica: The Physiognomic Characterization. M. Sc. Thesis, University of Miami, Miami, Florida. 130 p.

Jiménez, J. A. (1984). A hypothesis to explain the reduced distribution of the mangrove Pelliciera rhizophoraeTr. \& Pl. Biotropica, 16, 304-308.

Jiménez, J.A. (1988). Floral and fruiting phenology of trees in a mangrove forest on the dry Pacific coast of Costa Rica. Brenesia, 29, 33-50.

Jiménez, J. A. (1994). Los manglares del Pacifico Centroamericano. Heredia, Costa Rica: EFUNA. 352 p.

Jiménez, J.A. (1999). Ambiente, distribución y características estructurales en los manglares del Pacífico de Centroamérica: Constrastes climáticos. In: A. YáñezArancibia, \& A.L. Lara-Domínguez (eds.), Ecosistemas de Manglar en América Tropical (pp. 51-70). México: Instituto de Ecología, A.C.;Costa Rica: UICN/HORMA;Silver Spring, Maryland: NOAA/ NMFS. 
Jiménez, J.A., \& Soto, R. (1985). Patrones regionales en la estructura y composición florística de los manglares de la Costa Pacífica de Costa Rica. Revista de Biología Tropical, 33, 25-37.

Kathiresan, K., \& Bingham, B. L. (2001). Biology of mangroves and mangrove ecosystems. Advances in Marine Biology, 40, 81-251.

Nellemann, C., Corcoran, E., Duarte, C. M., Valdés, L., De Young, C., Fonseca, L., Grimsditch, G. (eds). 2009. Blue Carbon: A Rapid Response Assessment. United Nations Environment Programme, GRID-Arendal. Norway: BirkelandTrykkeri AS.

Pizarro, F., \& Angulo, H. (1994). Diagnóstico de los manglares de la costa Pacífica de Costa Rica. In: J.F. Angulo, \& H. Suman (eds.), El ecosistema de manglar en América Latina y la Cuenca del Caribe: su manejo y conservación (pp. 34-63). Miami, Florida: University of Miami.

Pool, D. J., Snedaker, S. C., \& Lugo, A. E. (1977). Structure of mangroveforests in Florida, Puerto Rico, Mexico, and Costa Rica. Biotropica, 9, 195-212.
Ramsar (1999). Ficha informativa sobre humedales Ramsar. Manglar de Potrero Grande. http://www.wetlands.org/reports/ris/6CR008en_FORMER_1999.pdf

Samper-Villarreal, J., Cortés, J., \& Benavides-Varela, C. (2012).Description of the Panamá and Iguanita mangrove forest of Bahía Culebra, North Pacific coast of Costa Rica. Revista de Biología Tropical, 60 (Supplement 2), 109-120.

Silva-Benavides, A.M. (2009). Mangroves.In: I. S. Werthmann, \& J. Cortés (Eds.). Marine Biodiversity of Costa Rica, Central America (pp. 123-130). Berlin: Springer + Bussiness Media.

Soto, R., \& Jiménez, J. A. (1982). Análisis fisionómico estructural del manglar de Puerto Soley, La Cruz, Guanacaste, Costa Rica. Revista Biología Tropical, 30, 161-168.

Zamora-Trejos, P., \& Cortés, J. (2009). Los manglares de Costa Rica: Pacífico norte. Revista Biología Tropical, 57, 473-488. 
